\title{
Research on Nutrition and Dietetic Undergraduates in Terms of Their Information Level and Views About Genetically Modified Organisms
}

\author{
Seydi Yıkmış ${ }^{1 *}$, Başak Gökçe Çöl ${ }^{2}$ \\ $I^{\prime *}$ Department of Nutrition and Dietetics, School of Health Sciences, Tekirdă̆ Namık Kemal University, 59030 Tekirdağ, Turkey \\ Corresponding author, E-mail: syikmis@hotmail.com, ORCID: https://orcid.org/0000-0001-8694-0658 \\ ${ }^{2}$ Department of Nutrition and Dietetics, School of Health Sciences, Istanbul Gelişim University, 34310 Istanbul, Turkey \\ E-mail:bgcol@gelisim.edu.tr, ORCID: https://orcid.org/0000-0002-7627-9867
}

\begin{tabular}{l|l}
\hline A R T I C L E I N F O & A B S T R A C T \\
\hline Research Article & $\begin{array}{l}\text { This study aims to investigate the views and awareness level of nutrition and dietetics } \\
\text { undergraduates about genetically modified organisms (GMO). A total of 228 university students } \\
\text { participated in the research (130 female, 98 male students). During data collection, 8 open-ended } \\
\text { questions and attitude scale questionnaire (30 questions) were applied in order to determine the } \\
\text { demographic features and GMO knowledge of students. Students' replies to questions; "Do you } \\
\text { think GMO technology is beneficial or harmful? If it's beneficial, why? If it is harmful, why?" } \\
76.8 \% \text { stated that they found it harmful. To the question, "if it is harmful why?" students replied, } \\
\text { Received : 27/09/2018 } \\
\text { Accepted : 26/12/2018 } \\
\text { "they cause cancer". There is a statistical difference between the answers of first and third-year } \\
\text { students. To the question, "have you heard about the precautions that were taken by the ministry? } \\
\text { If yes, do you think they are sufficient?" 76.80\% students stated that they were not aware of the } \\
\text { precautions that were taken by the ministry. 53 participants replied to this question as "I have an } \\
\text { Genetically modified organism } \\
\text { idea about this." But to the question "Is it sufficient?" they stated that they are not sure about it. } \\
\text { Biotechnology } \\
\text { Food } \\
\text { Food chain } \\
\text { Scho is a statistical difference between graduates of Vocational High School and Anatolian High } \\
\text { but they experience confusion. Most of the students believe that GMO technology is harmful and } \\
\text { has some conceptual errors. Positive and negative sides of GMO technology should be expressed } \\
\text { clearly. It was concluded that course curriculums should include topics that will increase } \\
\text { knowledge and awareness related to GMOs. Additionally, courses can be given selectively in the } \\
\text { field of biotechnology so that confusion about GMO's can be eliminated. }\end{array}$ \\
\hline
\end{tabular}

(c) () () (9) This work is licensed under Creative Commons Attribution 4.0 International License

\section{Introduction}

The global population is rising annually, with most of this increasingly visible in underdeveloped and developing countries. With this rapid rise in the population, hunger rates are also increasing. Environmental conditions in various countries are changing in a negative direction. The reduced yield per unit area in agriculture decreases in the quality of products, along with an increase in the use of pesticide and fertilizers lead to the destruction of the ecosystem. However, it is suggested that the problem may be solved with new studies in the area of biotechnology and nutrition by reducing the use of pesticides (Erbaş, 2008; Kaynar, 2009; Sökmen, 2005). Biotechnology puts a premium on human health and the environment. With the help of recombinant DNA (rDNA) technology, biotechnology uses all or part of living organisms, in order to produce or reproduce materials that cannot be reproduced or which cannot be obtained as expressed in all of the technologies utilized (Babaoğlu et al., 2001; Eser, 2000; Haspolat, 2012). In recent years, with the advancements in the science of genetics and molecular biology, the concept of GMO is among the most debated topics in the scientific community and the public
(Haspolat, 2012; Kidman, 2010; Zhang and Guo, 2011).

GMOs are described as the organism(s) that is created using genetic engineering techniques. The genes that occur as a result of changing to a new organism is called GMO. GMOs are known as transgenic organisms, genetically modified organisms, or bio-engineered organisms (Klop and Severiens, 2007; Kulaç et al., 2006; Uzogara, 2000). The main intended usages of genetically modified products in the field of agriculture are increasing crop yield, reducing the use of pesticides, \& increasing the intensity of the aroma and taste of agricultural products, along with nourishing properties (Çelik and Balık, 2007; Murrell, 2013; Özdemir et al., 2010; Özmert and Yaman, 2015).

In addition to the positive views about GMOs, there are also negative views present. It is believed that foods that are produced using gene technology will: increase levels of allergic reactions, have unknown harmful effects and lead to a rapid increase in an antibiotic resistant microorganism. From an ecological perspective, GMOs will reduce the genetic diversity of the world. From an economic perspective, economic dependence will also increase, with small farmers suffering the most (Butler and 
Reichhardt, 1999; Council, 2000; Kulaç et al., 2006). The genetically modified organism Monsanto's MON 810 maize varieties were also banned in France, Germany, Hungary, Greece, Bulgaria, Austria, and Luxembourg (Çıvgın, 2016). Novel and unconventional foods and GMOs present a challenge because of the complexity of the food composition. This diversity of foods is recognized in the legislative approach adopted internationally and, in the principle, that safety assessment should be approached on a case-by-case basis. The ADI that typically includes a 100 -fold safety margin when compared with the lowest NOAEL seen in toxicology studies does not seem feasible for the majority of novel foods. Complete freedom from risk is an unattainable goal, thus the circumstances and degree of exposure to the food in question become a crucial consideration (Pressman et al., 2017). It is believed that most societies do not have enough information on GMOs. For this purpose, various questionnaires were designed and significant findings were obtained (Özdemir et al., 2010). According to research conducted by Green Peace, it was found that school canteens are not healthy. Thirteen school canteens were investigated and determined that more than half of the canteens used GMOs that contain soy. After the regulatory GMO labeling requirement for the use of GMOs, it was found that usage of GMO containing products declined $10 \%$ (Finucane, 2002). It is claimed that the majority of students from primary school to university have incomplete and inaccurate information about biotechnology (Dawson, 2007; Özden et al., 2002).

According to research conducted in Taiwan, $60 \%$ of Taiwanese find GMOs unsafe (Chen and Li, 2007). In the survey about GMO food safety between expert scientists and the general public, differences in opinion have been observed (Hilbeck et al., 2015). In another study carried out in Italy, it is stated that social responsibility entrepreneurs have positive effects on consumers' buying intentions of GMO (Pino et al., 2016). Half of 322 college students are given the redaction text in order to change the attitude, emotions and conceptual knowledge towards GM foods. The other half constitutes the control group. Eventually, among the student groups who read the text, it was determined that emotions for genetically modified foods became more positive and negative (Heddy et al., 2016).

In a study where Polish citizens' $(n=1021)$ knowledge and attitude level were investigated, it is found that they are against the production and sale of GMO products in the Polish market or they preferred labeling of any product that contains a component of GMO (Rzymski and Królczyk, 2016). In the research conducted with 163 Historical Black University students on animal welfare and agricultural practices, females have a more negative attitude $(\mathrm{P}=0.03)$ than males (Rippeto et al., 2016). In another survey conducted in Australia about society, $(\mathrm{N}=8221)$ the issue of moral acceptability and the significance of media was discussed (Marques et al., 2015). Furthermore, Mexican natives' perception and attitudes about GMOs was found to be very low $(31.28 \%)$. They were reportedly insecure about GMOs and desired transgenic products to be labeled (93.59\%) (López Montesinos et al., 2016). In a study conducted in Sweden, $20 \%$ of the population were found eager to buy GMO, while $80 \%$ were suspicious about GMOs (Lehrman and Johnson, 2008).
There are few literary studies, investigating GMO knowledge and attitudes of university-level students towards it. This study is aimed to reveal the knowledge level of the students who are receiving education in the nutrition and dietetics department.

\section{Materials and Methods}

\section{Sample}

The sample consisted of a total of 228 university students who studied in the Nutrition and Dietetics Department of Health college of the Foundation University in Istanbul.

\section{Data Collection and Analysis}

In the study designed according to the descriptive scanning model (Güriş and Astar, 2015), three scale forms (Personal Information, Knowledge Level, and Attitude) was used as a data collection tool. The first section contains demographic data. The second part consists of 8 openended questions prepared to measure the level of knowledge of students about Genetically Modified Organisms. The third part of the questionnaire consists of 30 Likert type attitude items with the form of "Never Agree", "Partially Agree", "Neutral" and "Absolutely Agree" in order to determine students' attitudes towards GMOs. The reliability of the measurement tool was calculated (Cronbach-Alpha) and the reliability coefficient of the test was 0.764 . The obtained data were evaluated using frequency (f), percentage (\%), independent groups ttest and one-way variance analysis (ANOVA) method with SPSS (Statistical Package for Social Sciences) 20.0 program. The test result obtained the significance level (p) between the groups. There is a difference if $\mathrm{P}<0.05$ and no difference if $\mathrm{P}>0.05$.

\section{Factor Analysis of the Survey}

For the validity of groupings, primarily for the operations between two substances, (factor) factor analysis was conducted. During the factor analysis process, KaiserMeyer-Olkin (KMO) and Bartlett values are determined. Principal component analysis has been performed, and finally upright spin (equal rotation) of the operations reviewed. KMO test is done to determine that partial correlations distribution are adequate for factor analysis. In this study, the KMO value was positive. The result of Bartlett's test found 2475,447 ( $\mathrm{P}<0.001)$. The significance of the Bartlett values of the data also supports the hypothesis that they come from a multivariate normal distribution.

Table $1 \mathrm{KMO}$ and Barlett's Test Values

\begin{tabular}{ll|c}
\hline $\begin{array}{l}\text { Kaiser-Meyer-Olkin Measure of Sampling } \\
\text { Adequacy }\end{array}$ & 0.723 \\
\hline Bartlett's Test of & Ki-kare Value & 2475.447 \\
Sphericity & df & 435 \\
& Sig. & 0 \\
\hline
\end{tabular}

As a result of factor analysis measurement items are divided into 5 groups. Table 5 demonstrates the defined groups. 
Table 2 Groups decided as a result of factor analysis

\begin{tabular}{c|l}
\hline Group & \multicolumn{1}{|c}{ No } \\
\hline A & $1,2,5,7,16,19,20,25$ \\
B & $11,15,18,21,22,28$ \\
C & $6,9,13,23,24$ \\
D & $8,10,14,17,29$ \\
E & $3,4,26,27,30$ \\
\hline
\end{tabular}

\section{Results and Discussion}

Frequency and percentages are given in Table 3 according to the results of the demographic data on students participating in the study.

Table 3 Demographic data of the sampling group

\begin{tabular}{|c|c|c|c|}
\hline Demographic & Category & $\mathrm{F}$ & $(\%)$ \\
\hline \multirow{2}{*}{ Gender } & Female & 130 & 57 \\
\hline & Male & 98 & 43 \\
\hline \multirow{4}{*}{ Grade } & 1st Class & 58 & 25.4 \\
\hline & 2. Class & 55 & 24.1 \\
\hline & 3rd Class & 57 & 25 \\
\hline & 4th grade & 58 & 25.4 \\
\hline \multirow{6}{*}{ Graduation } & Vocational High School & 25 & 11 \\
\hline & Anatolian High School & 141 & 61.8 \\
\hline & Technical High School & 6 & 2.6 \\
\hline & Science high school & 31 & 13.6 \\
\hline & Religious High School & 6 & 2.6 \\
\hline & Other & 19 & 8.3 \\
\hline \multirow{5}{*}{$\begin{array}{l}\text { Mother } \\
\text { Education }\end{array}$} & Uneducated & 8 & 3.5 \\
\hline & Primary education & 82 & 36 \\
\hline & High School & 87 & 38.2 \\
\hline & Licence & 48 & 21.1 \\
\hline & Graduate & 3 & 1.3 \\
\hline \multirow{7}{*}{ Region } & Marmara & 105 & 46.1 \\
\hline & Aegean & 11 & 4.8 \\
\hline & Mediterranean & 32 & 14 \\
\hline & Black Sea & 21 & 9.2 \\
\hline & Eastern Anatolia & 31 & 13.6 \\
\hline & Southeastern Anatolia & 22 & 9.6 \\
\hline & Central Anatolia & 6 & 2.6 \\
\hline \multirow{5}{*}{$\begin{array}{l}\text { Monthly } \\
\text { Income }\end{array}$} & $1500 \mathrm{TL}$ and below & 10 & 4.4 \\
\hline & $1501-3000$ & 66 & 28.9 \\
\hline & $3001-4500$ & 67 & 29.4 \\
\hline & $4501-6000$ & 59 & 25.9 \\
\hline & $6001-7500$ & 26 & 11.4 \\
\hline \multirow{5}{*}{$\begin{array}{l}\text { Father } \\
\text { Education }\end{array}$} & Uneducated & 7 & 3.1 \\
\hline & Primary Education & 53 & 23.2 \\
\hline & High School & 94 & 41.2 \\
\hline & Licence & 60 & 26.3 \\
\hline & Graduate & 14 & 6.1 \\
\hline
\end{tabular}

F: Frequency

The findings of the frequency (f) and percent (\%) values obtained as a result of the analysis related to the questions in the GMO Knowledge Test prepared in the second part of the study are given in Table 4.

When Table 5 is examined, the answers of students in the Nutrition and Dietetics section to the first question are as follows: what they hear most from television (60); (56), book (77), teacher (21), newspapers and magazines (12) and other sources (2). There was no statistically significant difference between the responses of the students to the questions of the differences between the classes $(\mathrm{P}>0.05)$.

The answers given by the students to the second question are as follows: fruits (24), vegetables (25), corn (105), foods (29), wheat (40) and others (5). There was no statistically significant difference between the answers were given by the students in the first, second, third and fourth grades $(\mathrm{P}>0.05)$. This question was found to be statistically different between vocational high school graduates and Anatolian high school graduates $(\mathrm{P}<0.05)$.

The answer to the third question of the students is as follows: $76.8 \%$ stated that they found harmful. Students responded with the phrase "cancer makes the most" for the question "If it is harmful, why?" It was observed that there was a statistically significant difference between the answers of the first and third-year students $(\mathrm{P}<0.05)$. This question was found to be statistically different between Vocational High School graduates and Anatolian High School graduates $(\mathrm{P}<0.05)$.

The answer to the 4th question is as follows: Of 204 respondents $(8.5 \%)$ answered as yes. Table 4 . shows that there is a statistical difference between the responses of the students of the nutrition and dietetics to the questions of gender differences $(\mathrm{P}<0.05)$.

The answer to the 5th question by the students of the nutrition and dietetic department is as follows: $76.80 \%$ stated that there is no knowledge. 53 participants who say "I have knowledge" were not sure about the answers they gave to the question "is enough?" It was observed that there was a statistically significant difference between the answers of the first and second-grade students in the students $(\mathrm{P}<0.05)$.

The answer to the 6th question of the students is as follows: 76 people (35.5\%) responded "no". It was observed that there was a statistical difference between the answers of the gender differences in the questions of the students of the cookery program and that the perceptions of men were higher $(\mathrm{P}<0.05)$. The answer given by the students to the 7th question is as follows: 204 people $(89.5 \%)$ answered yes. No responders were found to be unclear in the answer. For the 7th question, 139 respondents (61\%) answered yes. For the answer "no", there was often insufficient supervision among the answers given by the participants.

The answer given by the students to the eighth question is as follows: 54 people $(23.7 \%)$ responded as "no". The ones who said "yes" are 174 participants, 83 people in the Ministry of Food, Agriculture, and Livestock, 65 Ministry of Health, 19 municipalities and 7 people left empty. There was no statistically significant difference between the answers of the students of nutrition and dietetics according to their gender, class and internet usage status $(\mathrm{P}>0.05)$.

There was no statistically significant difference between the responses of the students of the nutrition and dietetics to the open-ended questions of regional and maternal education levels ( $>>0.05)$. When family income was analyzed according to the income level, it was found that there was a statistical difference between the answers to the other questions except the 7th and 8th questions $(\mathrm{P}<0.05)$. 
Table 4 Frequency and percentages of open-ended questions

\begin{tabular}{|c|c|c|c|c|}
\hline No & Open-ended Question & Ans & $\mathrm{F}$ & $\%$ \\
\hline \multirow{2}{*}{1} & \multirow{2}{*}{ [ave you ever heard of the term GMO? If so, which source or sources did $y$} & Yes & 226 & \\
\hline & & No & 2 & 0,9 \\
\hline \multirow[b]{2}{*}{2} & \multirow{2}{*}{$\begin{array}{l}\text { Do you think there is any food product you consume in terms of GMOs? If yes, which } \\
\text { food are you worried about? }\end{array}$} & Yes & 195 & 86 \\
\hline & & No & 33 & 15 \\
\hline \multirow{2}{*}{3} & \multirow{2}{*}{$\begin{array}{l}\text { Do you think GMO technology is useful or harmful? If it is useful, why? If it is harmful, } \\
\text { why? }\end{array}$} & Us & 53 & 23 \\
\hline & & Harn & 175 & 77 \\
\hline \multirow{2}{*}{4} & \multirow{2}{*}{ Do GMOs make any changes to the food? If yes, how is it? } & Yes & 204 & \\
\hline & & $\mathrm{N}$ & 24 & \\
\hline \multirow{2}{*}{5} & \multirow{2}{*}{$\begin{array}{l}\text { Do you have any information about the measures the Ministry has taken regarding the use } \\
\text { of GMOs? If so, is it enough? }\end{array}$} & Yes & 53 & 23 \\
\hline & & No & 175 & 77 \\
\hline \multirow[t]{2}{*}{6} & \multirow{2}{*}{$\begin{array}{l}\text { Do you check the information label while purchasing food products? If so, what features } \\
\text { do you consider first? }\end{array}$} & Yes & 204 & 90 \\
\hline & & No & 24 & 11 \\
\hline \multirow[t]{2}{*}{7} & \multirow{2}{*}{ Do you think that the GMO warnings on food labels are re } & Yes & 139 & 61 \\
\hline & & No & 89 & \\
\hline \multirow{2}{*}{8} & \multirow{2}{*}{$\begin{array}{l}\text { Do you know where you will go when you learn that a food you buy contains GMOs? If } \\
\text { yes, where are these institutions? }\end{array}$} & Yes & 174 & 76 \\
\hline & & No & 54 & \\
\hline
\end{tabular}

Table 5 T-test results of open-ended questions by gender

\begin{tabular}{l|ccccc}
\hline No & $\mathrm{t}$ & $\mathrm{df}$ & Sig. (2-tailed) & Mean Difference & Std. Error Difference \\
\hline 1 & -0.2 & 226 & 0.841 & -0.003 & 0.013 \\
2 & 0.448 & 226 & 0.654 & 0.021 & 0.047 \\
3 & 1.656 & 226 & 0.099 & 0.093 & 0.056 \\
4 & -2.05 & 226 & 0.041 & -0.084 & 0.041 \\
5 & 0.069 & 226 & 0.945 & 0.005 & 0.066 \\
6 & -0.56 & 226 & 0.575 & -0.032 & 0.057 \\
7 & 0.632 & 226 & 0.528 & 0.041 & 0.066 \\
8 & 1.778 & 226 & 0.077 & 0.101 & 0.057 \\
\hline
\end{tabular}

\section{Analysis of the Attitudinal Scale Related to GMOs}

Independent groups t-test and One-way ANOVA test were used to examine the effect of students on GMO attitudes. The interviews were conducted on an average scale of 1 and 5 points for students' responses to GMO attitude scale items. The average scores of students' attitude scale items for GMOs are shown in Table 6, 7, 8, 9 and 10.

Independent groups t-test was used to examine the effect of sex of students' attitudes towards GMOs. The test results are shown in Table 6. According to the scores given to the statements "GMO causes cancers" and "GMO is one of the ways in which people earn commercial income", the gender was found to be a statistically different difference between the students' GMO attitudes $(\mathrm{P}<0.05)$. Signs that they gave to other items indicate that the genders of the students have no significant effect on GMO attitudes $(\mathrm{P}>0.05)$.

Anova test was used to investigate the effect of class differences on GMO attitudes of students. There was a statistically significant difference between first and fourthyear students according to student responses in the 1st place $(\mathrm{P}<0.05)$. According to the markings made by the students in the 2nd place, it was found that there is a statistical difference between the 2nd and 3rd-year students. The class differences of students indicate that there is no significant effect on GMO attitudes on other items $(\mathrm{P}>0.05)$.

According to the One-way ANOVA results made according to the regions where the students came from, it was found that there is a statistical difference between Eastern Anatolian region and the Marmara region in the 4th question of table 1 . In the answer given by the students to item 7, it was found that the Marmara region is statistically different between the Black Sea region and the
Mediterranean region. It is found that there is a statistical difference between the Eastern Black Sea region and the Marmara region in the 13 th place $(\mathrm{P}<0.05)$. The regional differences of the learners indicate that there is no significant effect on GMO attitudes on other subjects $(\mathrm{P}>0.05)$.

According to the One-way ANOVA results made according to the graduation of the students, it was found that there is a statistical difference between Vocational High School, Imam Hatip High School and Technical High School in the 13th article. In the answer given by the students to item 17 , it was found that there is a statistical difference between the vocational high school, the Anatolian high school, and the science high school $(\mathrm{P}<0.05)$. It shows that there is no significant effect on GMO attitudes on the subjects according to the graduation status of the students $(\mathrm{P}>0.05)$.

According to the One-way ANOVA results of the students according to their mother's education level, there was a statistically important difference between the graduates of secondary education and graduate schools in the 19th article and the p-value was found as $0,09(\mathrm{P}<0.05)$. It shows that there is no significant effect of the students on the GMO attitudes on the materials according to the maternal education level status $(\mathrm{P}>0.05)$.

According to the results of ANOVA made according to the level of education of the fathers, it was found that there is a statistical difference between the primary and the uneducated ones. In the answer given by students to item 10 , it was found that there was a statistical difference between all groups. In the answer given by the students to item 15 , it is found that there is a statistical difference between primary education, uneducated and secondary school graduates. 
Table 6 Average scores of students' attitudes toward GMOs (A group)

\begin{tabular}{c|lc}
\hline No & \multicolumn{1}{|c}{ Students' Attitude Scale for GMOs } & Mean \\
\hline 1 & The Genetically Modified Organism is suited to ethical rules. & 2.08 \\
2 & Risks associated with GMO products can be accepted to benefit from their benefits. & 2.41 \\
5 & Consumption of GMO-containing products causes people to die prematurely. & 3.21 \\
7 & GMOs are one of the ways in which people earn commercial income. & 4.08 \\
16 & GMO foods are a major breakthrough. & 3.02 \\
19 & GMO crop production is free in our country. & 3.28 \\
20 & GMO products have the same properties as natural products. & 2.03 \\
25 & I consume genetically modified corn and corn-derived oil. & 2.5 \\
\hline
\end{tabular}

Table 7 Average scores of students' attitudes toward GMOs (B group)

\begin{tabular}{c|lc}
\hline No & Students' Attitude Scale for GMOs & Mean \\
\hline 11 & One of the areas where gene transfer is used in plants is to obtain more resistant strains. & 3.36 \\
15 & GMO breaks the food chain in nature. & 3.85 \\
21 & Gene transfer is a fast and cost-effective method. & 3.2 \\
22 & I think it is appropriate to change the genes to ensure that fruits and vegetables stay fresh for a long time. & 2.33 \\
28 & Hunger can be avoided with GMO products. & 2.85 \\
\hline
\end{tabular}

Table 8 Average Scores of Students' Attitudes toward GMOs (C group)

\begin{tabular}{c|lc}
\hline No & Students' Attitude Scale for GMOs & Mean \\
\hline 6 & GMOs can cause illness in the future generation of children. & 4.00 \\
9 & GMOs cause effects that cannot be detected today. & 3.79 \\
13 & It is not safe to consume food with GMOs. & 3.79 \\
23 & GMO products increase the nutritional value of food. & 2.25 \\
24 & Environmental organizations exaggerate the risks associated with food with GMOs. & 2.30 \\
\hline
\end{tabular}

Table 9 Average Scores of Students' Attitudes toward GMOs (D group)

\begin{tabular}{c|lc}
\hline No & \multicolumn{1}{|c}{ Students' Attitude Scale for GMOs } & Mean \\
\hline 8 & The effects of the GMO will increase. & 3.97 \\
10 & GMO will lead to non-recyclable adverse effects. & 3.84 \\
14 & I do not consume genetically modified tomatoes. & 3.38 \\
17 & I Consume rice prepared from genetically modified rice. & 2.72 \\
29 & GMO products have toxic effects on the human body. & 3.57 \\
\hline
\end{tabular}

Table 10 Average Scores of Students' Attitudes toward GMOs (E group)

\begin{tabular}{c|lc}
\hline No & \multicolumn{1}{|c}{ Students' Attitude Scale for GMOs } & Mean \\
\hline 3 & GMOs harm animals. & 3.77 \\
4 & GMO causes cancers. & 3.84 \\
26 & GMO products have an allergic effect on the human body. & 3.53 \\
27 & I think that international brands' products are more likely to contain GMOs than domestic producers. & 3.48 \\
30 & GMO products affect species diversity and balance in the ecosystem. & 3.89 \\
\hline
\end{tabular}

Table $11 \mathrm{P}$ values according to the gender of the students according to attitude scale items of GMO

\begin{tabular}{c|ccccc}
\hline No & Sig. (2-tailed) & No & Sig. (2-tailed) & No & Sig. (2-tailed) \\
\hline 1 & 0.158 & 11 & 0.238 & 21 & 0.582 \\
2 & 0.898 & 12 & 0.913 & 22 & 0.63 \\
3 & 0.261 & 13 & 0.967 & 23 & 0.626 \\
4 & 0.014 & 14 & 0.351 & 24 & 0.854 \\
5 & 0.168 & 15 & 0.49 & 25 & 0.658 \\
6 & 0.25 & 16 & 0.565 & 26 & 0.453 \\
7 & 0.005 & 17 & 0.481 & 27 & 0.391 \\
8 & 0.064 & 18 & 0.116 & 28 & 0.79 \\
9 & 0.058 & 19 & 0.495 & 29 & 0.844 \\
10 & 0.144 & 20 & 0.395 & 30 & 0.269 \\
\hline
\end{tabular}


There is a statistical difference between 6001-7500 TL and $1500 \mathrm{TL}$ and below in 6th place according to One-way ANOVA results made according to the average family income level of the students. In the answer given by the students to item 12, it was found that there is a statistical difference between all groups. In the answer given by the students to item 14 , it is found that there is a statistical difference between 6001-7500 TL, 4501-6000 TL and $1500 \mathrm{TL}$ and below. The $\mathrm{p}$ values given according to the items were found as $0.01,0.009,0.001$ respectively $(\mathrm{P}<0.05)$. It shows that there is no meaningful effect of GMO attitudes on the students according to the average family income level of the students $(\mathrm{P}>0.05)$.

In the researches, it was determined that the medical school students' risk perceptions of genetically modified foods were high but their knowledge level was not sufficient (Keskin et al., 2010; Yanpar et al., 2010). Similar findings were found in a study conducted on health vocational students (Ergin et al., 2015). They found that university students had inconsistency with the lack of knowledge about the production, use, prevalence and possible risks of GMOs in their study (Özden et al., 2013). When literature studies are examined, we see that there are not enough studies involving university students' knowledge levels of biotechnology and biotechnology interviews. When similar studies are examined, these research findings show that students do not have enough knowledge about GMOs and biotechnology. This result is compatible with other studies in the literature.

\section{Conclusion}

Today, the developments in biotechnology are rapidly developing and this is affecting our daily life. It has been understood that students have sufficient basic knowledge about genetically modified organisms, but that some concepts are misleading and that a large majority think that genetic material replacement technology is harmful. Globally, the distribution of genetically modified organisms and food products containing them is rapidly increasing. These issues have a direct impact on our daily lives and need to be examined more. The nutritional and dietetic graduates have a great deal of food consumption and advice. Students in the nutrition and dietetics departments have more exposure to the issues that describe the potential benefits and risks of GMOs and biotechnology incremental and subtractive learning play as a key to community awareness. It is thought that the subjects related to the biotechnology courses will give detailed information about the positive and negative aspects of the work done in recent years in the curriculum and providing more information about GMOs will help to misunderstand the concepts and inform the society correctly.

\section{References}

Babaoğlu M, Gürel E, Özcan, S. 2001. Bitki Biyoteknolojisi Doku Kültürü Ve Uygulamaları - M.Babaoğlu, E.Gürel, S.Özcan. Nadir Kitap. Konya.

Butler D, Reichhardt T, 1999. Long-term effect of GM crops serves up food for thought. Nature 398, p. 651-653. doi:10.1038/19381
Çelik V, Balık DT. 2007. Genetiği değiştirilmiş organizmalar (GDO). Erciyes Üniversitesi Fen Bilim. Enstitüsü Derg. 23, p. 13-23.

Chen MF, Li HL, 2007. The consumer's attitude toward genetically modified foods in Taiwan. Food Qual. Prefer. 18, p. 662-674. doi:10.1016/j.foodqual.2006.10.002

Çıvgın H. 2016. Biosafety Board Decisions According to International Conventions and to GMO Regulation in Turkey. Educ. Sci. Soc. J. 14, p. 112-139.

Council, NR. 2000. Genetically Modified Pest-Protected Plants. National Academies Press, Washington, D.C. doi:10.17226/9795

Dawson V. 2007. An Exploration of High School (12-17 Year Old) Students' Understandings of, and Attitudes Towards Biotechnology Processes. Res. Sci. Educ. 37, p. 59-73. doi:10.1007/s11165-006-9016-7

Erbaş H. 2008. Türkiye'de Biyoteknoloji ve Toplumsal Kesimler, 4th ed. Ankara Üniversitesi Biyoteknoloji Enstitüsü. doi:10.1501/ankara-3464

Ergin Uzun S, Bozkurt A. 2015. Pamukkale Üniversitesi Tip Fakültesi öğrencilerinin genetiği değiştirilmiş organizmalarla ilgili bilgi ve görüşleri. Pamukkale Tıp Derg. 8, p. 92-98. doi: $10.5505 /$ ptd.2015

Eser V. 2000. Modern Biyoteknolojideki Gelişmelerin Işı̆̆ Altında Dünya ve Türkiye'de Tarım, in: Küreselleşme Sürecinde Biyogüvenlik Sempozyumu Bildiri Özetleri. Ankara.

Finucane ML. 2002. Mad cows, mad corn and mad communities: the role of socio-cultural factors in the perceived risk of genetically-modified food. Proc. Nutr. Soc. 61, p. 31-7.

Göktan G. 2002. Disiplinlerarası Uygulama Alanı Olan Biyoteknolojinin Kimya Eğitiminde Yeri ve Önemi. Hacettepe Üniversitesi, Fen Bilimleri Enstitüsü,Ankara.

Güriş S, Astar M. 2015. Bilimsel Araştırmalarda SPSS ile İstatistik. Der yayınları.

Haspolat I. 2012. Genetiği değiştirilmiş organizmalar ve biyogüvenlik Iraz HASPOLAT. Ankara Üniv Vet Fak Derg 59, p. 75-80.

Heddy BC, Danielson RW, Sinatra GM, Graham J. 2016. Modifying Knowledge, Emotions, and Attitudes Regarding Genetically Modified Foods. J. Exp. Educ. p. 1-21. doi:10.1080/00220973.2016.1260523

Hilbeck A, Binimelis R, Defarge N, Steinbrecher R, Székács A, Wickson F, Antoniou M, Bereano PL, Clark, EA, Hansen M, Novotny E, Heinemann J, Meyer H, Shiva V, Wynne B. 2015. No scientific consensus on GMO safety. Environ. Sci. Eur. 27, p. 4. doi:10.1186/s12302-014-0034-1

Kaynar P. 2009. Genetik Olarak Değiştirilmiş Organizmlar (GDO)'a Genel Bir Bakış. Türk Hij. ve Deney. Biyol. Derg. 66, p. 177-185.

Keskin Y, Lüleci NE, Özyaral O, Altıntaş Ö, Sağlık A, Lisar H, Turan A, Top Y. 2010. Maltepe Üniversitesi Tip Fakültesi Öğrencilerinin Genetiği Değiştirilmiş Organizmalar Hakkında Bilgi Tutum ve Davranışları. Maltepe Üniversitesi Tıp Fakültesi Öğrencilerinin Genet. Değiştirilmiş Org. Hakkında Bilgi Tutum ve Davranışları 2, p. 14-23.

Kidman G. 2010. What is an 'Interesting Curriculum' for Biotechnology Education? Students and Teachers Opposing Views. Res. Sci. Educ. 40, 353-373. doi:10.1007/s11165009-9125-1

Klop T, Severiens S. 2007. An Exploration of Attitudes towards Modern Biotechnology: A study among Dutch secondary school students. Int. J. Sci. Educ. 29, p. 663-679. doi:10.1080/09500690600951556

Kulaç İ, Ağırdil Y, Yakın M. 2006. Sofralarımızdaki Tatlı Dert Genetiği Değiştirilmiş Organizmalar ve Halk Sağlığına Etkileri. Türk Biyokim. Derg. 31, p. 151-155.

Lehrman A, Johnson K. 2008. Swedish farmers attitudes, expectations and fears in relation to growing genetically modified crops. Environ. Biosafety Res. 7, p. 153-162. doi:10.1051/ebr:2008012 
López Montesinos OA, Pérez EF, Fuentes EES, Luna-Espinoza I, Cuevas FA, 2016. Perceptions and attitudes of the Mexican urban population towards genetically modified organisms. Br. Food J. 118, p. 2873-2892. doi:10.1108/BFJ-06-20160247

Marques MD, Critchley CR, Walshe J. 2015. Attitudes to genetically modified food over time: How trust in organizations and the media cycle predict support. Public Underst. $\quad$ Sci. $24, \quad$ p. $601-618$. doi:10.1177/0963662514542372

Murrell F. 2013. What is genetically modified food, why is it controversial and how do I know if I'm eating it? J. Home Econ. Inst. Aust. 20, 2.

Özdemir O, Handan Güneş M, Demir S. 2010. Üniversite Öğrencilerinin Genetiği Değiştirilmiş Organizmalara (GDO’lara) Yönelik Bilgi Düzeyleri-Tutumları ve Sürdürülebilir Tüketim Eğitimi Açısından Değerlendirilme. Ondokuz Mayıs Üniversitesi Eğitim Fakültesi Derg. 29, 53 68.

Özden M, Akgün A, Çinici A, Gülmez H. 2013. 8. Sınıf Öğrencilerinin Genetiği Değiştirilmiş Organizmalar (GDO) Hakkındaki Bilgi Düzeyleri ve Biyoteknolojiye Yönelik Tutumlarının İncelenmesi. Adıyaman Univ. J. Sci. 3, 94-115.

Özden M, Usak M, Prokop P, Türkoglu A, Bahar M. 2002. African journal of biotechnology. African J. Biotechnol. 7, 3892-3899.

Özmert S, Yaman H. 2015. Tüketicilerin Genetiği Değiştirilmiş Gıdalara Karşı Tutumlarının ve Bilgi Düzeylerinin Belirlenmesi. Kocatepe Vet. Derg. 4.
Pino G, Amatulli C, De Angelis M, Peluso AM. 2016. The influence of corporate social responsibility on consumers' attitudes and intentions toward genetically modified foods: evidence from Italy. J. Clean. Prod. 112, 2861-2869. doi:10.1016/j.jclepro.2015.10.008

Pressman P, Clemens R, Hayes W, Reddy C. 2017. Food additive safety: A review of toxicologic and regulatory issues. Toxicol. Res. Appl. 1, 1-22. doi:10.1177/2397847317723572

Rippeto JD, Cash KA, Shanks BC, Caldwell JD, Aruguete MS. 2016. 423 College student perceptions of animal welfare and production agriculture practices at a small Historical Black University. J. Anim. Sci. 94, 197. doi:10.2527/msasas2016423

Rzymski P, Królczyk A. 2016. Attitudes toward genetically modified organisms in Poland: to GMO or not to GMO? Food Secur. 8, 689-697. doi:10.1007/s12571-016-0572-z

Sökmen MA. 2005. Genetik Yapısı Değiştirilmiş Bitkiler ve Bitki Koruma Amaçlı Kullanımı. Anadolu Tarım Bilim. Derg. 20, 105-109. doi:10.7161/ANAJAS.2005.20.3.105-109

Uzogara SG. 2000. The impact of genetic modification of human foods in the 21st century: a review. Biotechnol. Adv. 18, 179206.

Yanpar H, Müftüoğlu S, Saka M. 2010. Tip Fakültesi Öğrencilerinin Genetiği Değiş̧tirilmiş Organizmalar Hakkında Bilgi, Tutum ve Davranışlarının Belirlenmesi. Adnan Menderes Üniversitesi Sağlık Bilim. Fakültesi Derg. $2,12-20$.

Zhang D, Guo J. 2011. The Development and Standardization of Testing Methods for Genetically Modified Organisms and their Derived ProductsF. J. Integr. Plant Biol. 53, 539-551. doi:10.1111/j.1744-7909.2011.01060.x 